\title{
ANALISIS KUALITAS KINERJA PRAMUWISATA TERHADAP KEPUASAN WISATAWAN JEPANG PADA PARADISE BALI TOUR AND TRAVEL DI BADUNG
}

\author{
Arya Adi Palguna \\ I Made Sendra \\ I Nyoman Sudiarta \\ Email : aryapalguna@gmail.com \\ PS. S1 Industri Perjalanan Wisata \\ Fakultas Pariwisata UNUD
}

\begin{abstract}
The type of data used are qualitative and quantitative data, while-for the data source is the primary and secondary data. Techniques of data collection is conducted through observation, interviews, and questionnaires. The sampling technique used purposive sampling i.e. applied particular consideration determined by the researcher itself. In another words the researchers have their own criteria toward the Japanese tourists who had ever utilized the services of Paradise Bali Tour and Travel.

The result of this study shows that tourists are satisfied by the performance of the Japanese tour guides in Paradise Bali Tour and Travel, with an average rate of suitability is 74.39 percent. Being used Cartesian diagram to analyze the indicators to be a top priority and must be done in accordance with expectations of tourists, such as: guides appearance and neatness and another items and must be used by guide when pick-up the guests, providing clear and accurate information about the condition of destination, and efficiency of time and speedy when pick up the tourists. Indicators are considered important and needed to be maintained its performance are the mastering of foreign languages by guides in order to fluent communication, the courtesy of guides when providing services. Indicators considered less important by tourists but its implementation is quite well done, namely responsiveness guides in providing clear and concise information. Indicator that overestimated by tourist but it have done very well, such as the convenience of tourists when receiving services from the guide during the tour taken place.
\end{abstract}

Keywords $\quad$ : Quality and Satisfaction Rating.

\section{PENDAHULUAN}

Bali merupakan salah satu destinasi pariwisata yang terkenal dan banyak wisatawan berkunjung ke Bali, salah satunya adalah wisatawan Jepang. Paradise Bali Tour and Travel, merupakan salah satu travel agent yang khusus menangani wisatawan Jepang yang berwisata ke Bali. Paradise Bali Tour and Travel berlokasi di jalan Raya Tuban No 99x Tuban, Paradise Bali Tour and Travel melayani wisatawan Jepang dengan menyediakan jasa pemesanan kamar hotel, paket wisata, check in, check out, transfer, car charter dan pramuwisata yang mengantarkan wisatawan dengan mengedepankan keramahan serta pelayanan yang berkualitas. Kunjungan wisatawan Jepang yang menggunakan jasa Paradise Bali Tour and Travel dari tahun 2009-2013 seperti tertera pada tabel 1.1 berikut ini. 
Tabel 1.1

Kunjungan wisatawan Jepang yang menggunakan jasa Paradise Bali Tour and Travel Tahun 2009-2013

\begin{tabular}{|l|c|c|c|c|c|}
\hline \multirow{3}{*}{ Bulan } & \multicolumn{5}{|c|}{ Tahun } \\
\cline { 2 - 6 } & $\begin{array}{c}2009 \\
\text { (orang) }\end{array}$ & $\begin{array}{c}2010 \\
\text { (orang) }\end{array}$ & $\begin{array}{c}2011 \\
\text { (orang) }\end{array}$ & $\begin{array}{c}2012 \\
\text { (orang) }\end{array}$ & $\begin{array}{c}2013 \\
\text { (orang) }\end{array}$ \\
\hline Januari & 154 & 166 & 237 & 233 & 218 \\
\hline Februari & 161 & 238 & 243 & 237 & 219 \\
\hline Maret & 153 & 247 & 237 & 214 & 211 \\
\hline April & 144 & 187 & 156 & 161 & 206 \\
\hline Mei & 130 & 198 & 151 & 200 & 204 \\
\hline Juni & 211 & 210 & 192 & 234 & 230 \\
\hline Luli & 147 & 194 & 147 & 142 & 198 \\
\hline Agustus & 150 & 220 & 168 & 185 & 171 \\
\hline September & 150 & 230 & 269 & 219 & 175 \\
\hline Oktober & 185 & 256 & 225 & 149 & 138 \\
\hline November & 157 & 269 & 190 & 174 & 184 \\
\hline Desember & 85 & 186 & 140 & 217 & 190 \\
\hline Total & 1827 & 2601 & 2355 & 2365 & 2344 \\
\hline
\end{tabular}

Sumber: Paradise Bali Tour and Travel 2013

Pada tabel 1.1 menunjukkan wisatawan jepang yang menggunakan jasa Paradise Bali Tour and Travel mengalami fluktuasi yang di sebabkan beberapa faktor. Pada tahun 20092010 terjadi peningkatan sebesar 774 orang, namum pada tahun 2010-2011 kunjungan wisatawan mengalami penurunan sebesar 246 orang, pada tahun 2011-2012 kunjungan mengalami peningkatan dengan jumlah 10 orang dan pada tahun 2012-2013 kunjungan wisatawan kembali mengalami penurunan sebanyak 21 orang. Maka untuk mengetahui penyebab fluktuasi ini dilakukan penelitian tentang kepuasan wisatawan yang menggunakan jasa dari pramuwisata pada Paradise Bali Tour and Travel.

\section{METODE PENELITIAN}

Penelitian sebelumnya dilakukan oleh Mukhles Al-Ababneh tahun 2013 yang memiliki persamaan dengan penelitian ini yait. sama-sama mengukur tingkat kepuasan wisatawan terhadap kualitas pelayanan pramuwisata dan perbedaanya dapat dilihat dari alat ukur yang digunakan. Penelitian selanjutnya dilakukan oleh Yiqian Peng tahun 2013, memiliki persamaan adalah sama-sama meneliti tentang tingkat kepuasan wisatawan dan menggunakan skala likert sebagai alat ukurnya, namun perbedaanya terletak pada teknik analisis yang digunakan.

Pengumpulan data dilakukan dengan cara menyebarkan kuisioner kepada wisatawan Jepang yang sudah menggunakan jasa Paradise Bali Tour and Travel, studi kepustakaan serta dokumentasi. Sedangkan
Teknik pengambilan sampel menggunakan Purposive sampling yaitu pengambilan sampel yang ditentukan oleh penulis sendiri yaitu wisatawan Jepang yang sudah menggunakan jasa Paradise Bali Tour and Travel dengan menggunakan analisis kinerja dan kepentingan yaitu dengan mengalikan indikator pertanyaan dari 5 sampai dengan 10 indikator, maka dengan demikian jumlah sampel sebanyak 75 orang responden.

Teknik analisis data yang digunakan adalah teknik analisis data deskriptif kuantitatif dengan menggunakan skala likert 5 jenjang seehingga dapat diketahui letak dari indikator tersebut menjadi sebuah poin yang dapat diprioritaskan, serta menggunakan diagram kartesius yang dapat menentukan posisi sebuah poin pertanyaan dan serta tingkat kesesuaian untuk menentukan prioritas poin dari pertanyaan.

\section{HASIL DAN PEMBAHASAN}

Terdapat 15 faktor analisis kualitas pelayanan perusahaan terdapat 2 buah variabel yaitu $\mathrm{X}$ yang merupakan variabel dari penilaian terhadap kinerja karyawan pada Paradise Bali Tour and Travel dan Y merupakan tingkat kepentingan pelayanan pada Paradise Bali Tour and Travel bagi wisatawan, dengan menggunakan rumus importance-performance analysis untuk menghitung tingkat kesesuaian, akan menghasilkan prosentase wisatawan mengenai kepuasan pelayanan jasa pada Paradise Bali Tour and Travel. Tabulasi ratarata penilaian kinerja dan penilaian kepentingan dapat dilihat pada tabel 2.1 berikut ini.

Tabel 2.1

Tabulasi Rata-Rata Penilaian Kinerja dan Penilaian Kepentingan yang Mempengaruhi Kualitas Pelayanan Pramuwisata Terhadap Kepuasan Wisatawan Pada Paradise Bali Tour and Travel.

\begin{tabular}{|c|c|c|c|c|c|}
\hline No & Indikator & $\overline{\mathrm{X}}$ & $\overline{\mathrm{Y}}$ & $\overline{\bar{X}}$ & $\overline{\bar{Y}}$ \\
\hline 1 & \begin{tabular}{lr}
\multicolumn{2}{l}{ Penampilan } \\
kerapian pramuwisata \\
saat & memandu \\
wisatawan & \\
\end{tabular} & 230 & 342 & 3,06 & 4,56 \\
\hline 2 & $\begin{array}{l}\text { Perlengkapan } \\
\text { yang digunakan }\end{array}$ & 214 & 334 & 2,85 & 4,45 \\
\hline
\end{tabular}




\begin{tabular}{|c|c|c|c|c|c|}
\hline & $\begin{array}{l}\text { pramuwisata untuk } \\
\text { memandu wisatawan } \\
\text { saat menjalankan tour }\end{array}$ & & & & \\
\hline 3 & 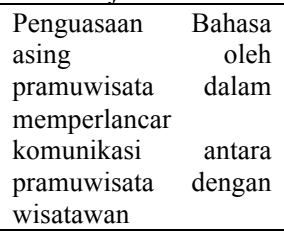 & 269 & 348 & 3,58 & 4.64 \\
\hline 4 & $\begin{array}{l}\text { Pramuwisata } \\
\text { memberikan informasi } \\
\text { yang jelas dan benar } \\
\text { sesuai } \\
\begin{array}{l}\text { keadaan di dengan } \\
\text { wisata }\end{array} \\
\end{array}$ & 225 & 330 & 3,0 & 4,4 \\
\hline 5 & $\begin{array}{lr}\text { Efisiensi r waktu } \\
\text { dan kecepatan } \\
\text { saat pramuwisata } \\
\text { melakukan } \\
\text { penjemputan } \\
\text { wisatawan }\end{array}$ & 204 & 335 & 2.72 & 4,46 \\
\hline 6 & $\begin{array}{l}\text { Pramuwisata } \\
\text { membantu wisatawan } \\
\text { bila diperlukan pada } \\
\text { saat tour }\end{array}$ & 245 & 347 & 3,26 & 4,62 \\
\hline 7 & $\begin{array}{l}\text { Pramuwisata } \\
\text { mampu memberikan } \\
\text { kesan yang baik } \\
\text { kepada wisatawan } \\
\text { saat tour berakhir }\end{array}$ & 204 & 337 & 2,72 & 4,49 \\
\hline 8 & $\begin{array}{l}\text { Daya } \\
\text { tanggap pramuwisata } \\
\text { dalam memberikan } \\
\text { informasi secara } \\
\text { singkat dan jelas }\end{array}$ & 250 & 294 & 2,73 & 3.92 \\
\hline 9 & $\begin{array}{lr}\text { Mengerti dengan cepat } \\
\text { dan tanggap } & \text { apa } \\
\text { yang diinginkan } & \text { dan } \\
\begin{array}{l}\text { dibutuhkan } \\
\text { wisatawan }\end{array} & \text { oleh } \\
\end{array}$ & 235 & 344 & 3,13 & 4,58 \\
\hline 10 & $\begin{array}{lr}\text { Masalah } & \text { yang } \\
\text { dihadapi wisatawan } \\
\text { dapat diatasi }\end{array}$ & 240 & 331 & 3,2 & 4,41 \\
\hline 11 & $\begin{array}{lr}\text { Ketegasan } & \\
\text { pramuwisata } & \text { dalam } \\
\text { mengambil } & \text { keputusan } \\
\text { dimana } & \text { ada } \\
\text { permasalahan } & \\
\end{array}$ & 267 & 314 & 3,56 & 4.18 \\
\hline 12 & $\begin{array}{lr}\text { Kenyamanan } \\
\text { wisatawan raat } \\
\text { menerima pelayanan } \\
\text { dari pramuwisata } \\
\text { selama rar } \\
\text { berlangsung } \\
\end{array}$ & 237 & 332 & 3,16 & 4,42 \\
\hline 13 & $\begin{array}{l}\text { Kesopanan } \\
\text { pramuwisata saat } \\
\text { memberikan pelayanan } \\
\text { kepada wisatawan }\end{array}$ & 256 & 327 & 3,41 & 4,36 \\
\hline 14 & $\begin{array}{lr}\text { Sikap } & \text { pramuwisata } \\
\text { dalam } & \text { memberkan } \\
\text { salam saat akan } \\
\text { memulai tour }\end{array}$ & 227 & 330 & 3,02 & 4,4 \\
\hline 15 & $\begin{array}{l}\text { Kemampuan } \\
\text { pramuwisata } \\
\text { menciptakan suasana } \\
\text { yang mengyenangkan } \\
\text { dan mengasyikkan saat } \\
\text { tour berlangsung }\end{array}$ & 291 & 329 & 3.88 & 4,38 \\
\hline & Rata - rata & 3594 & 4974 & 3.3 & 4.28 \\
\hline
\end{tabular}

Sumber: Diperoleh dari Hasil Penelitian Tahun 2015.
Pada tabel 2.1 dapat dilihat rata-rata dari tingkat kinerja dan kepentingan mengenai kepuasan wisatawan dengan hasil rata-rata dari keseluruhan tingkat kinerja yaitu sebesar 3,3 dan rata-rata dari keseluruhan tingkat kepentingan adalah sebesar 4,28.

Berikut ini merupakan tingkat kesesuaian masing-masing indikator yang merupakan hasil dari perbandingan skor kinerja dengan skor kepentingan yang digunakan untuk menentukan skala prioritas layanan dan perbaikan untuk mencapai kepuasan pelanggan. Tingkat kesesuaian indikator yang mempengaruhi kepuasan wisatawan yang menggunakan jasa Paradise Bali Tour and Travel dapat dilihat pada tabel berikut ini.

Tabel 2.2

Tingkat Kesesuaian Indikator yang Mempengaruhi Kepuasan Wisatawan yang Menggunakan Jasa Paradise Bali Tour and Travel

\begin{tabular}{|c|c|c|c|}
\hline No & Indikator & $\begin{array}{c}\text { Tingkat } \\
\text { Kesesuaian } \\
\text { Iindikator } \\
(\%)\end{array}$ & Ket \\
\hline 1 & $\begin{array}{l}\text { Penampilan dan } \\
\text { kerapian } \\
\text { pramuwisata } \\
\text { saat memandu } \\
\text { wisatawan }\end{array}$ & 67,25 & Cukup Puas \\
\hline 2 & $\begin{array}{l}\text { Perlengkapan } \\
\text { yang digunakan } \\
\text { pramuwisata untuk } \\
\text { memandu } \\
\text { wisatawan } \\
\text { saat menjalankan } \\
\text { tour }\end{array}$ & 64,07 & Cukup Puas \\
\hline 3 & $\begin{array}{l}\text { Penguasaan Bahasa } \\
\text { asing oleh } \\
\text { pramuwisata } \\
\text { dalam } \\
\text { memperlancar } \\
\text { komunikasi antara } \\
\text { pramuwisata } \\
\text { dengan wisatawan }\end{array}$ & 77,29 & Cukup Puas \\
\hline 4 & $\begin{array}{l}\text { Pramuwisata } \\
\text { memberikan } \\
\text { informasi yang } \\
\text { jelas dan benar } \\
\text { sesuai dengan } \\
\begin{array}{l}\text { keadaan di destinasi } \\
\text { wisata }\end{array} \\
\end{array}$ & 68,18 & Cukup Puas \\
\hline 5 & $\begin{array}{lr}\text { Efisiensi } & \text { waktu } \\
\text { dan kecepatan } \\
\text { saat pramuwisata } \\
\text { melakukan } \\
\text { penjemputan } \\
\text { wisatawan }\end{array}$ & 60,89 & Cukup Puas \\
\hline 6 & Pramuwisata & 70,60 & Cukup Puas \\
\hline
\end{tabular}




\begin{tabular}{|c|c|c|c|}
\hline & $\begin{array}{l}\text { membantu } \\
\text { wisatawan } \\
\text { diperlukan } \\
\text { saat } \text { tour }\end{array}$ & & \\
\hline 7 & $\begin{array}{l}\text { Pramuwisata } \\
\text { mampu } \\
\text { memberikan kesan } \\
\text { yang baik kepada } \\
\text { wisatawan saat tour } \\
\text { berakhir }\end{array}$ & 60.35 & Cukup Puas \\
\hline 8 & $\begin{array}{l}\text { Daya } \\
\text { tanggap } \\
\text { pramuwisata } \\
\text { dalam memberikan } \\
\text { informasi secara } \\
\text { singkat dan jelas } \\
\end{array}$ & 69,72 & Cukup Puas \\
\hline 9 & $\begin{array}{lr}\text { Mengerti } & \text { dengan } \\
\text { cepat dan } & \text { tanggap } \\
\text { apa } & \text { yang } \\
\text { diinginkan } & \text { dan } \\
\text { dibutuhkan } & \text { oleh } \\
\text { wisatawan } & \\
\end{array}$ & 68,31 & Cukup Puas \\
\hline 10 & $\begin{array}{l}\text { Masalah yang } \\
\text { dihadapi wisatawan } \\
\text { dapat diatasi }\end{array}$ & 72,50 & Cukup Puas \\
\hline 11 & $\begin{array}{l}\text { Ketegasan } \\
\text { pramuwisata dalam } \\
\text { mengambil } \\
\text { keputusan dimana } \\
\text { ada permasalahan }\end{array}$ & 85,03 & Puas \\
\hline 12 & $\begin{array}{l}\text { Kenyamanan } \\
\text { wisatawan saat } \\
\text { menerima } \\
\text { pelayanan dari } \\
\text { pramuwisata selama } \\
\text { tour berlangsung }\end{array}$ & 71,38 & Cukup Puas \\
\hline 13 & $\begin{array}{l}\text { Kesopanan } \\
\text { pramuwisata saat } \\
\text { memberikan } \\
\text { pelayanan kepada } \\
\text { wisatawan } \\
\end{array}$ & 78,28 & Cukup Puas \\
\hline 14 & $\begin{array}{l}\text { Sikap pramuwisata } \\
\text { dalam memberkan } \\
\text { salam saat akan } \\
\text { memulai tour }\end{array}$ & 68,78 & Cukup Puas \\
\hline 15 & $\begin{array}{l}\text { Kemampuan } \\
\text { pramuwisata } \\
\text { menciptakan } \\
\text { suasana yang } \\
\text { mengyenangkan } \\
\text { dan mengasyikkan } \\
\text { saat tour } \\
\text { berlangsung }\end{array}$ & 88.44 & Puas \\
\hline & Rata-rata & 74.395 & Cukup Puas \\
\hline
\end{tabular}

Sumber: Diperoleh dari Hasil Penelitian Tahun 2015.

Pada tabel 2.2 dapat dilihat persentase tanggapan responden pada masing-masing indikator berdasarkan tingkat kesesuaian setiap elemen kualitas pelayanan, dapat diukur sebagai berikut:

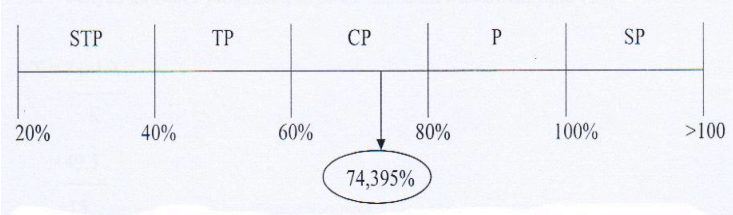

Dari gambar diatas dapat dilihat bahwa rata-rata tingkat kesesuaian dari keseluruhan indikator adalah 74,395\% dengan kategori cukup puas.

Selanjutnya akan menggambar diagram kartesius yang digunakan untuk mengetahui posisi dan indikator pertanyaan dengan menjadikan rata-rata dari rata-rata kinerja dan kepentingan yang mempengaruhi kepuasan wisatawan sebagai garis dasar untuk menggambarkan diagram tersebut. Diagram kartesius yang menunjukkan faktor yang mempengaruhi kualitas pelayanan pramuwisata terhadap kepuasan wisatawan Jepang pada Paradise Bali Tour and Travel dapat dilihat pada gambar 1 berikut ini.

Gambar 2.1

Diagram Kartesius dari Faktor yang Mempengaruhi Kualitas Pelayanan Pramuwisata terhadap Kepuasan Wisatawan Jepang pada Paradise Bali Tour and Travel.

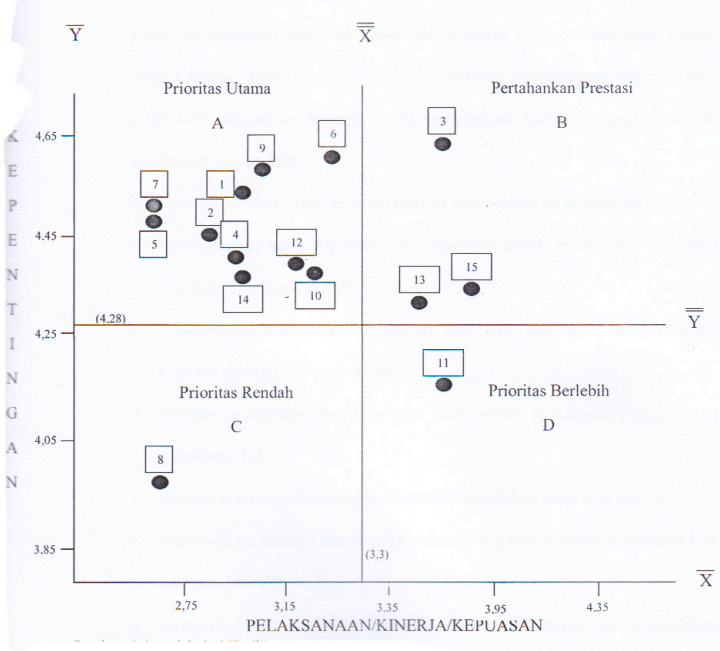

Sumber : Diperoleh dari Hasil Penelitian Tahun 2015

Dari hasil data pengolahan diagram kartesius dapat dijelaskan sebagai berikut:

Kuadran A

Prioritas utama. Sangat penting bagi wisatawan namun pelaksanaanya belum memuaskan bagi wisatawan:

1. Penampilan dan kerapian pramuwisata saat memandu wisatawan. (1) 
2. Perlengkapan yang digunakan pramuwisata untuk memandu wisatawan saat menjalankan tour. (2)

3. Pramuwisata memberikan informasi yang jelas dan benar sesuai dengan keadaan di destinasi wisata. (4)

4. Efisiensi waktu dan kecepatan saat melakukan penjemputan wisatawan. (5)

5. Pramuwisata membantu wisatawan bila diperlukan pada saat tour.(6)

6. Pramuwisata mampu memberikan kesan yang baik kepada wisatawan saat tour berakhir.(7)

7. Mengerti dengan cepat dan tanggap apa yang diinginkan dan dibutuhkan oleh wisatawan.(9)

8. Masalah yang dihadapi wisatawan dapat diatasi dengan segera.(10)

9. Kenyamanan wisatawan saat menerima pelayanan dari pramuwisata selama tour berlangsung.(12)

10. Sikap pramuwisata dalam memberikan salam saat akan memulai tour.(14)

Kuadran B

Pertahankan prestasi. Tingkat kepentingan dan pelaksanaanya sudah memuaskan wisatawan.

1. Penguasaan bahasa asing oleh pramuwisata dalam memperlancar komunikasi antara pramuwisata dengan wisatawan. (3)

2. Kesopanan seorang pramuwisata saat memberikan pelayanan kepada wisatawan.(13)

3. Kemampuan menciptakan pramuwisata
suasana yang menyenangkan danmengasikkan saat tour berlangsung.(1 5)

Kuadran C

Prioritas rendah. Faktor yang dianggap kurang penting namun pelaksanaanya biasa.

1. Daya tangkap pramuwisata dalam memberikan informasi secara singkat dan jelas.(8)

Kuadran D

Pelaksanaan yang berlebihan serta wisatawan menganggap tidak terlalu penting, namun pelaksanaanya dilakukan dengan sangat baik sehingga memuaskan wisatawan.
1. Kenyamanan wisatawan saa menerima pelayanan dari pramuwisataselama tour berlangsung.(11)

Dari pengolahan data diagram kartesius di atas serta penjabaran sesuai dengan kuadran masing-masing, maka dapat dibuat tabel prioritas yaitu tabel yang memperlihatkan indikator yang mendapatkan prioritas terendah dan tertinggi. Dimana indikator yang mendapatkan tingkat kesesuaian tertinggi tidak terlalu didahulukan untuk dibenahi oleh pihak Paradise Bali Tour and Travel. Sedangkan indikator yang memiliki tingkat kesesuaian rendah harus di perhatikan dan segera dibenahi. Adapun prioritas indikator kesesuaian pelayanan berdasarkan tingkat kesesuaian dapat dilihat pada tabel dibawah ini:

\section{Tabel 2.3}

Prioritas Indikator Kesesuaian Pelayanan Berdasarkan Tingkat Kesesuaian

\begin{tabular}{|c|c|c|c|}
\hline No & Indikator & $\begin{array}{c}\text { Tingkat } \\
\text { Kesesuaian }\end{array}$ & Prioritas \\
\hline 1 & $\begin{array}{l}\text { Pramuwisata mampu } \\
\text { memberikan kesan yang } \\
\text { baik kepada wisatawan } \\
\text { saat tour berakhir. }\end{array}$ & $60,39 \%$ & I \\
\hline 2 & $\begin{array}{l}\text { Efisiensi waktu dan } \\
\text { kecepatan } \\
\text { pramuwisata melakukan } \\
\text { penjemputan wisatawan. }\end{array}$ & $60,98 \%$ & II \\
\hline 3 & $\begin{array}{l}\text { Perlengkapan yang } \\
\text { digunakan pramuwisata } \\
\text { untuk memandu wisatawan } \\
\text { saat menjalankan tour. }\end{array}$ & $64,07 \%$ & III \\
\hline 4 & $\begin{array}{l}\text { Penampilan dan kerapian } \\
\text { pramuwisata } \\
\text { memandu wisatawan. }\end{array}$ & $67,25 \%$ & IV \\
\hline 5 & \begin{tabular}{lrr}
\multicolumn{2}{l}{ Pramuwisata memberikan } \\
informasi yang jelas dan \\
benar sesuai & dengan \\
keadaan di & destinasi \\
wisata. & & \\
& & \\
&
\end{tabular} & $68,18 \%$ & V \\
\hline 6 & $\begin{array}{l}\text { Mengerti dengan cepat dan } \\
\text { tanggap apa yang } \\
\text { diinginkan dan dibutuhkan } \\
\text { oleh wisatawan. }\end{array}$ & $68,31 \%$ & VI \\
\hline 7 & $\begin{array}{l}\text { Sikap pramuwisata dalam } \\
\text { memberikan salam saat } \\
\text { akan memulai tour. }\end{array}$ & $68,78 \%$ & VII \\
\hline 8 & $\begin{array}{l}\text { Daya tanggap pramuwisata } \\
\text { dalam } \\
\text { informasi secara singkat } \\
\text { dan jelas. }\end{array}$ & $69,72 \%$ & VIII \\
\hline 9 & $\begin{array}{ll}\text { Pramuwisata membantu } \\
\text { wisatawan bila diperlukan }\end{array}$ & $70,60 \%$ & IX \\
\hline
\end{tabular}




\begin{tabular}{|c|c|c|c|}
\hline & pada saat tour. & & \\
\hline 10 & $\begin{array}{l}\text { Kenyamanan wisatawan } \\
\text { saat menerima pelayanan } \\
\text { dari pramuwisata selama } \\
\text { tour berlangsung. }\end{array}$ & $71,38 \%$ & $\mathrm{X}$ \\
\hline 11 & $\begin{array}{l}\text { Masalah yang dihadapi } \\
\text { wisatawan dapat diatasi } \\
\text { dengan segera. }\end{array}$ & $72,50 \%$ & XI \\
\hline 12 & $\begin{array}{l}\text { Penguasaan bahasa asing } \\
\text { oleh pramuwisata dalam } \\
\text { memperlancar komunikasi } \\
\text { antara pramuwisata dengan } \\
\text { wisatawan. }\end{array}$ & $77,29 \%$ & XII \\
\hline 13 & $\begin{array}{lr}\text { Kesopanan } & \text { seorang } \\
\text { pramuwisata } & \text { saat } \\
\text { memberikan pelayanan } \\
\text { kepada wisatawan. }\end{array}$ & $78,28 \%$ & XIII \\
\hline 14 & $\begin{array}{lr}\text { Ketegasan } & \text { seorang } \\
\text { pramuwisata } & \text { dalam } \\
\text { mengambil } & \text { keputusan } \\
\text { dimana ada } & \text { permasalahan } \\
\text { saat } \text { tour. } & \\
\end{array}$ & $85,03 \%$ & XIV \\
\hline 15 & $\begin{array}{l}\text { Kemampuan pramuwisata } \\
\text { menciptakan suasana yang } \\
\text { menyenangkan dan } \\
\text { mengasikkan saat tour. }\end{array}$ & $88,44 \%$ & V \\
\hline
\end{tabular}

Berdasarkan tabel 2.3 dapat dilihat bahwa indikator yang mendapat prioritas pertama yaitu pramuwisata mampu memberikan kesan yang baik kepada wisatawan saat tour berakhir, memperoleh tingkat kesesuaian terendah yaitu $60,39 \%$. Sedangkan indikator yang memperoleh tingkat kesesuaian tertinggi yaitu kemampuan pramuwisata menciptakan suasana yang menyenangkan dan mengasyikkan saat tour berlangsung, mendapat prioritas terakhir sebesar $88,44 \%$.

\section{SIMPULAN DAN SARAN Simpulan}

Dari penelitian diatas dapat

disimpulkan bahwa :

Kuadran A yaitu prioritas yang utama dimana wisatawan merasa sangat penting namun pelaksanaannya belum memuaskan. Terbagi dalam beberapa indikator yaitu :

1. Penampilan dan kerapian pramuwisata saat memandu wisatawan.

2. Perlengkapan yang digunakan pramuwisata untuk memandu wisatawan saat menjalankan tour.

3. Pramuwisata memberikan informasi yang jelas dan benar sesuai dengan keadaan di destinasi wisata.

4. Efisiensi waktu dan kecepatan saat pramuwisata melakukan penjemputan wisatawan.
Kuadran B yaitu tingkat kepentingan dan pelaksanaanya sudah memuaskan wisatawan, yaitu :

1. Penguasaan bahasa asing oleh pramuwisata dalam memperlancar komunikasi antara pramuwisata dengan wisatawan.

2. kesopanan seorang pramuwisata saat memberikan pelayanan kepada wisatawan.

3. kemampuan pramuwisata menciptakan suasana yang menyenangkan dan mengasikkan saat tour berlangsung.

Kuadran C faktor yang dianggap kurang penting namun pelaksanaanya biasa, yaitu :

1. Daya tangkap pramuwisata dalam memberikan informasi secara singkat dan jelas.

Dan yang terakhir adalah kuadran D Pelaksanaan yang berlebihan serta wisatawan menganggap tidak terlalu penting, namun pelaksanaanya dilakukan dengan sangat baik sehingga memuaskan wisatawan, yaitu:

1. Kenyamanan wisatawan saat menerima pelayanan dari pramuwisata selama tour berlangsung.

\section{Saran}

Berdasarkan simpulan diatas, maka didapatkan beberapa saran bagi pramuwisata Jepang pada Paradise Bali Tour and Travel, antara lain yaitu :

1. Sebaiknya agar pramuwisata dapat memperhatikan penampilan pada saat melakukan tour, karena dari kerapian dan penampilan yang baik maka mencerminkan kepribadian dari pramuwisata itu sendiri.

2. Hendaknya pramuwisata juga memperhatikan dalam ketegasan untuk mengambil keputusan apabila terjadi masalah atau complain saat tour berlangsung.

3. Agar pramuwisata lebih memperhatikan perlengkapan yang mereka gunakan untuk memandu wisatawan saat tour berlangsung, seperti kotak P3K (pertolongan pertama pada kecelakaan), microphone dan itinerary (rencana program perjalanan). 
Jurnal IPTA

ISSN : 2338-8633

Vol. 3 No. 2, 2015

\section{DAFTAR PUSTAKA}

Al-Ababneh, Mukhles.2013. "Service Quality and its Impact on Tourist Satisfaction".

Paradise Bali Tour and Travel 2014

Sugiyono. 2014. "Metode Penelitian Kuaantitatif, Kualitatif dan $R \& D$ ". Bandung.

Supranto, J. 2006. Pengukuran Tingkat Kepuasan Pelanggan Untuk Menaikkan PangsaPasar. Jakarta : PT. Rineka Cipta.

Yiqian, Peng. 2013. "Customer Satisfaction of Mainland Chinese Tourist in Cairns Australia, International Refreed Research Journal. 